\title{
Workload and work motivation relationships with nursing performance
}

\author{
Rizky Amalia Kinanti ${ }^{1}$, Kris Linggardini ${ }^{2}$ \\ ${ }^{1,2}$ Department of Nursing, Faculty of Health Sciences, Universitas Muhammadiyah Purwokerto, Indonesia
}

\begin{tabular}{l} 
ARTICLE INFO \\
\hline Article history: \\
Received: August 9, 2020 \\
Revised: August 20, 2020 \\
Accepted: August 30, 2020 \\
\hline
\end{tabular}

\section{Keywords:}

Workload, Work motivation, Performance, Nurses.

\begin{abstract}
Some provinces in Indonesia have been conducted by the directorate of health care service in 2004 with $\mathrm{WHO}$, as a result that $70,4 \%$ of nurses have never had training, 39,8\% of nurses at the hospital performed non nursing duties, $47,4 \%$ of non essential written duties. No specialized supervision and evaluation of nurses. According to interviews with some nurses in the Purbalingga Regency said the nurses' workload was high because of the extra work off-duty and the function of a nurse. The objective for knowing the relationship of workload and work motivation with a nurse's performance. This type of research is quantitative using a descriptive design correlation with a sectional cross. The population in this study is all the nurses in the Kutasari medikal center, the Purbalingga Center, the Kalikajar Center and the Kaligondang medical center in Purbalingga District. The sampling technique used is total sampling that is 33 respondents. Analysis used statistics in the chi square. Statistics in this study consist of frequency workload, work motivation and nurse performance. From the results of data processing, it is found that there is a relationship between workload and nurses' performance with a pvalue of $0.017<0.05$. And there's no connection between work motivation with nurse performance with p-value of $0.422>0.05$. There is a correlation between workload and nurse performance and no correlation between work motivation and nurse performance.
\end{abstract}

This work is licensed under a Creative Commons Attribution 4.0 International License.

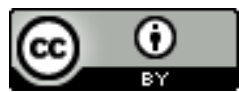

Corresponding Author:

Rizky Amalia Kinanti,

Department of Nursing, Faculty of Health Sciences,

Universitas Muhammadiyah Purwokerto,

Suparjo Rustam Road KM 7, Purwokerto, 53186, Indonesia.

Email: liaamalia.rak@gmail.com

\section{INTRODUCTION}

Public Health Center as one of the technical implementing units of the District/City Health Office is the first level implementing unit as well as the pioneer of health development including health services in Indonesia. With the success of District/City in achieving minimum service standards is strongly influenced by the performance of Public Health Center which is supported by professional health workers including nurses who are expected to be able to provide optimal nursing services to the community. [1]

Workload is the average frequency of each job within a certain time. Nursing is activities performed by nurses while working in a nursing service unit, workload is defined as patiens days which refers to the number of procedures, examination of visits to clients. [2] A number of factors can influence the good or poor work results or the performance of nurses, one of which is workload. [3]

Motivation comes from Latin, movere, which means move, encouragement or propulsion. This motivation is only given to humans, especially to subordinates or followers. Motivation questions on how to encourage the work and passion of subordinates so that they are willing to work hard by giving all their abilities and skills to achieve company goals. [4] Motivation is an encouragement both from others and from oneself to do a job consciously and enthusiastically to achieve certain targets. [5] 
Performance or work performance is the result of work in quality and quantity achieved by an employee in carrying out his duties in accordance with the responsibilities assigned to him. [6] The performance of nurses is closely related to the quality of nursing services provided. Several provinces in Indonesia, consisting of East Kalimantan, North Sumatra, North Sulawesi, West Java and DKI Jakarta have been researched by the Directorate of Nursing Services, Ministry of Health in collaboration with WHO (World Health Organization) in 2004, obtained results that over the last 3 years there were $70.9 \%$ of nurses have never attended training, $39.8 \%$ of nurses in hospitals do non-nursing tasks, $47.4 \%$ of nurses do not have clear and written dues, there has been no specific nurse supervision and evaluation. [7]

Efforts to improve the performance of health workers at Public Health Center are very important and have become demands because of various aspects related to efforts to improve health services. That includes abilities in terms of education, training, and length of work, as well as work motivation. In order to achieve good performance, these efforts must be implemented in an integrated and multi-disciplinary manner and involve all related health workers. [8] The purpose of the study was to determine the relationship between workload and work motivation with the performance of nurse.

\section{RESEARCH METHOD}

This study used a descriptive correlation design with a cross sectional approach. The sampling technique in this study was total sampling which collected by 33 respondents. Data collection used questionnaires and data analysis used Chi Square test. This research was conducted from April $15^{\text {th }}$ to June $8^{\text {th }} 2020$ at Purbalingga District Health Center.

\section{RESULTS AND DISCUSSIONS} 3.1 Respondent Characteristics

Table 1. Distribution of respondent characteristics in Public Health Center of Purbalingga Regency $(n=33)$

\begin{tabular}{lcc}
\hline Characteristics & Frequency & Percentage \\
\hline Age & 1 & \\
Late Teens 17-25 & 8 & $3.0 \%$ \\
Early Adulthood 26-35 & 14 & $24.2 \%$ \\
Late Adults 36-45 & 10 & $42.2 \%$ \\
Early Aged 46-55 & & $30.3 \%$ \\
Gender & 15 & \\
Male & 18 & $45.5 \%$ \\
Female & & $54.5 \%$ \\
Working period & 11 & \\
1-10 & 9 & $33.3 \%$ \\
$11-20$ & 10 & $27.3 \%$ \\
$21-30$ & 3 & $30.3 \%$ \\
31-40 & & $9.1 \%$ \\
Educated & 25 & \\
Diploma & 4 & $75.8 \%$ \\
Bachelor & 4 & $12.1 \%$ \\
Nurse Profesional & &
\end{tabular}

Based on table 1, the distribution of respondent characteristics according to age category is mostly late adults aged 36-45 years as many as 14 respondents (42.2\%). It states that the productive age range category is between 15-54 years, so the age of nurses is in the productive age category because most of them are in the age range of 36-45 years. [1] Most of the respondents were female as many as 18 respondents (54.5\%). In the theory of nursing by Florence Ninghtingle, it explained that female nurses are more sensitive in caring for someone who is sick or healthy, women also have a higher level of patience than men and maternal instinct in a woman causes many women to be needed in nursing than men. Most of the respondents' working period is in the range of 1-10 years as many as 11 respondents $(33.3 \%)$. It states that the more tenure the nurse has, the more experience the nurse has in providing nursing care in accordance with applicable standards or fixed procedures. And most of the respondents are D3 educated as many as 25 respondents (75.8\%). It states that people who have higher education will also have higher knowledge when compared to people who have low education and through education a person can increase intellectual maturity so as to make decisions in action. [9] A person's level of education has an influence in responding to something that comes from outside. 


\subsection{Workload}

Table 2. Workload at Public Health Center Kutasari, Public Health Center Purbalingga, Public Health Center Kalikajar and Public Health Center Kaligondang

\begin{tabular}{cccc}
\hline $\begin{array}{c}\text { Public Health } \\
\text { Center }\end{array}$ & Workload & Frequency & Percentage \\
\hline \multirow{2}{*}{ Kutasari } & Not Heavy & 3 & $42.9 \%$ \\
& Heavy & 4 & $57.1 \%$ \\
Purbalingga & Not Heavy & 1 & $16.7 \%$ \\
& Heavy & 5 & $83.3 \%$ \\
Kalikajar & Not Heavy & 2 & $20.0 \%$ \\
& Heavy & 8 & $80.0 \%$ \\
Kaligondang & Not Heavy & 3 & $30.0 \%$ \\
& Heavy & 7 & $70.0 \%$ \\
\hline
\end{tabular}

Based on table 2, obtained the results of the workload that at the Public Health Center Kutasari had 4 respondents (57.1\%) who experienced heavy workloads. At Public Health Center Purbalingga were 5 respondents (83.3\%). At Public Health Center Kalikajar were 8 respondents $(80.0 \%)$ and at Public Health Center Kaligondang had 7 respondents $(70.0 \%)$ who experienced heavy workload.

Table 3 Workload at Public Health Center of Purbalingga Regency

\begin{tabular}{lcc}
\hline Workload & Frequency & Percentage \\
\hline Not Heavy & 9 & $27.3 \%$ \\
Heavy & 24 & $72.7 \%$ \\
\hline Total & 33 & $100 \%$ \\
\hline
\end{tabular}

Based on table 3, obtained the results of the workload that at Public Health Center Kutasari, Public Health Center Purbalingga, Public Health Center Kalikajar and Public Health Center Kaligondang in Purbalingga Regency, most of the heavy work obtained 24 respondents $(72.7 \%)$ and the non-heavy work obtained 9 respondents $(27.3 \%)$.

\subsection{Work Motivation}

Table 4. Work Motivation at Public Health Center Kutasari, Public Health Center Purbalingga, Public Health Center Kalikajar and Public Health Center Kaligondang

\begin{tabular}{llcc}
\hline Public Health Center & Work Motivation & Frequency & Percentage \\
\hline Kutasari & Low & 2 & $28.6 \%$ \\
Purbalingga & High & 5 & $71.4 \%$ \\
\multirow{3}{*}{ Kalikajar } & Low & 1 & $16.7 \%$ \\
\multirow{2}{*}{ Kaligondang } & High & 5 & $83.3 \%$ \\
& Low & 3 & $30.0 \%$ \\
& High & 7 & $70.0 \%$ \\
& Low & 4 & $40.0 \%$ \\
\hline
\end{tabular}

Based on the table 4, obtained the results of work motivation at Public Health Center Kutasari had 5 respondents (71.4\%) who experienced high work motivation. At Public Health Center Purbalingga were 5 respondents (83.3\%). At Public Health Center Kalikajar sebanyak were 7 respondents $(70.0 \%)$ and at Public Health Center Kaligondang had 6 respondents (60.0\%) who experienced high work motivation.

Table 5. Work Motivation at Public Health Center of Purbalingga Regency

\begin{tabular}{lcc}
\hline $\begin{array}{l}\text { Work } \\
\text { Motivation }\end{array}$ & Frequency & Percentage \\
\hline Low & 10 & $30.3 \%$ \\
High & 23 & $69.7 \%$ \\
\hline Total & 33 & $100 \%$ \\
\hline
\end{tabular}

Based on the table 4.5, obtained the results of work motivation at Public Health Center Kutasari, Public Health Center Purbalingga, Public Health Center Kalikajar and Public Health Center Kaligondang in 
Purbalingga Regency, most of the high work motivation obtained 23 respondents $(69.7 \%)$ and the low work motivation obtained 10 respondents $(30.3 \%)$.

\subsection{Nurse Performance}

Table 6. Nurse Performance at Public Health Center Kutasari, Public Health Center Purbalingga, Public Health Center Kalikajar and Public Health Center Kaligondang

\begin{tabular}{llcc}
\hline Public Health Center & Nurse Performance & Frequency & Percentage \\
\hline Kutasari & Not Good & 2 & $28.6 \%$ \\
Purbalingga & Good & 5 & $71.4 \%$ \\
Kalikajar & Not Good & 2 & $33.3 \%$ \\
& Good & 4 & $66.7 \%$ \\
Kaligondang & Not Good & 1 & $10.0 \%$ \\
& Good & 9 & $90.0 \%$ \\
& Not Good & 1 & $10.0 \%$ \\
\hline
\end{tabular}

Based on the table 6, obtained the results of nurse performance at Public Health Center Kutasari had 5 respondents (71.4\%) who experienced good performance. At Public Health Center Purbalingga were 4 respondents (66.7\%). At Public Health Center Kalikajar were 9 respondents $(90.0 \%)$ and at Public Health Center Kaligondang had 9 respondents $(90.0 \%)$ who experienced good performance.

Table 7. Nurse Performance at Public Health Center of Purbalingga Regency

\begin{tabular}{lcc}
\hline Nurse Performance & Frequency & Percentage \\
\hline Not Good & 6 & $18.2 \%$ \\
Good & 27 & $81.8 \%$ \\
\hline Total & 33 & $100 \%$ \\
\hline
\end{tabular}

Based on the table 7, obtained the results of nurse performance at Public Health Center Kutasari, Public Health Center Purbalingga, Public Health Center Kalikajar and Public Health Center Kaligondang in Purbalingga Rgenecy, most of the good performance obtained 27 respondents $(81.8 \%)$ and the poor performance obtained 6 respondents $(18.2 \%)$.

\subsection{Bivariate Analysis Relationship of Workload with Nurse Performance}

Table 8. Relationship of Workload with Nurse Performance

\begin{tabular}{lccccccc}
\hline \multirow{3}{*}{ Workload } & \multicolumn{6}{c}{ Nurse Performance } & \multirow{2}{*}{ p-value } \\
\cline { 2 - 6 } & Not Good & \multicolumn{2}{c}{ Good } & \multicolumn{2}{c}{ Total } & \\
\cline { 2 - 6 } & $\mathbf{f}$ & $\mathbf{\%}$ & $\mathbf{f}$ & $\mathbf{\%}$ & $\mathbf{n}$ & $\boldsymbol{\%}$ & \\
\hline Not Heavy & 4 & 44.4 & 5 & 55.6 & 9 & 100.0 & \multirow{2}{*}{0.017} \\
Heavy & 2 & 8.3 & 22 & 91.7 & 24 & 100.0 & \\
\hline Total & 6 & 18.2 & 27 & 81.8 & 33 & 100.0 & \\
\hline
\end{tabular}

Based on the table 8, it showed that from 9 nurses who experienced heavy workload, 4 nurses (44.4\%) showed poor performance, and 5 nurses $(55.6 \%)$ showed good performance. Of the 24 nurses who experienced heavy workload, 2 nurses $(8.3 \%)$ showed poor performance, and 22 nurses $(91.7 \%)$ showed good performance. Based on the chi-square test, obtained p-value $0.017<0.05$, which means that there is a relationship between workload and the performance of nurses at the Public Health Center Purbalingga Regency. The results of this study are in line with research which states there is a relationship between workload and performance of health workers at the Public Health Center Bahu. [10] The relationship between work fatigue and the performance of nurses in the inpatient ward of the Islamic Hospital of Fatimah, Cilacap Regency, is classified as a high level of fatigue with a $63.8 \%$ percentage of fatigue levels, increasing fatigue can lead to decreased performance. [11]

Table 9. Relationship of Work Motivation with Nurse Performance

\begin{tabular}{lccccccc}
\hline \multirow{2}{*}{$\begin{array}{c}\text { Work } \\
\text { Motivation }\end{array}$} & \multicolumn{6}{c}{ Nurse Performance } & \multirow{2}{*}{ p-value } \\
\cline { 2 - 9 } & f & $\boldsymbol{\%}$ & $\mathbf{f}$ & $\boldsymbol{\%}$ & $\mathbf{n}$ & $\boldsymbol{\%}$ & \\
\hline Low & 1 & 10.0 & 9 & 90.0 & 10 & 100.0 & \multirow{2}{*}{0.422} \\
High & 5 & 21.7 & 18 & 78.3 & 23 & 100.0 & \\
\hline Total & 6 & 18.2 & 27 & 81.8 & 33 & 100.0 & \\
\hline
\end{tabular}


Based on table 4.2.2, it showed that from 10 nurses who stated low work motivation, 1 nurse (10.0\%) showed poor performance, and 9 nurses $(90.0 \%)$ showed good performance. Of the 23 nurses who stated high work motivation, 5 nurses $(21.7 \%)$ showed poor performance, and 18 nurses (78.3\%) showed good performance. Based on the chi-square test, obtained p-value 0.422>0.05, which means that there is no relationship between work motivation and nurse performance. The relationship between work motivation and the performance of nurses in the Work Area of the Public Health Center Tegal Ampel, Bondowoso Regency in 2016. Statistically, there is a relationship between motivation and the performance of inpatient nurses at the UPTD Kesehatan Tapung, Tapung District, Kampar Regency with a value of $p=0.004$ and POR $=10.50$ motivation of unmotivated nurses have a chance of 10.50 times more likely to not have good performance compared to nurses who are motivated.

\section{CONCLUSION}

The characteristics of respondents in Public Health Center Kutasari, Public Health Center Purbalingga, Public Health Center Kalikajar and Public Health Center Kaligondang in this study with the category of late adult age 36-45 years were 14 respondents (42.2\%), female gender were 18 respondents $(54.5 \%)$, working period 1-10 years were 11 respondents $(33.3 \%)$, and in the category of the highest education level, namely D3 were 25 respondents $(75.8 \%)$. Meanwhile, the nurse workload variable was mostly in the heavy category were 24 respondents $(72.7 \%)$. The work motivation of nurses is mostly in the high category of 23 respondents (69.7\%). Most of the performance of nurses was in the good category of 27 respondents $(81.8 \%)$. The results of the chi square test showed the value of $\rho=0.017(p<0.05)$, which means that there is a relationship between workload and nurse performance. And the chi square test results showed $\rho=0.422(p>0.05)$, which means that there is no relationship between work motivation and nurse performance. It is recommended that Public Health Center needs to improve the skills of nurses by increasing the education of nurses who were originally from diplomas to bachelor degree. It provides support and appreciation to nurses.

\section{REFERENCES}

[1] Depkes RI, Riset Kesehatan Dasar, Jakarta: Badan Penelitian dan pengembangan Kesehatan Kementrian Kesehatan RI, 2013.

[2] B. L. Marquis and C. J. Hounston, Kepemimpinan Dan ManagemenKeperawatan: Teori Dan Aplikasi, Jakarta: EGC, 2010.

[3] Sutrisno, "Faktor-faktor yang berhubungan dengan kinerja perawat rawat inap di RSUD Kota Semarang," Jurnal Kesehatan Masyarakat, vol. 5, no. 1, 2017.

[4] Fauzi and I. Rita, Pengantar Manajemen, Yogyakarta: ANDI, 2018.

[5] Mulyadi, Pengantar Manajemen, Bogor: IN MEDIA, 2016.

[6] Nursalam, Metodologi Penelitian Ilmu Keperawatan : Pendekatan Praktis, Jakarta: Salemba Medika, 2017.

[7] Kemenkes RI, Pedoman Pengembangan Manajemen Kinerja Perawat dan Bidan, Jakarta: Kemenkes, 2010.

[8] A. Imong, "Gambaran Kinerja tenaga kesehatan di Public Health Center Maritengngae Kabupaten Sidrap," Sekolah Tinggi Ilmu Kesehatan Baramuli, Kabupaten Sidrap, 2010.

[9] Notoatmodjo and Soekidjo, Metodologi Penelitian Kesehatan, Jakarta: Rineka Cipta, 2010.

[10] V. R. Yuckho, "Hubungan Antara Beban Kerja Dengan Kinerja Tenaga Kesehatan Di Public Health Center Bahu Kota Manado," Jurnal KESMAS Universitas Sam Ratulangi Manado,, 2014.

[11] D. Solikhah, "Hubungan Kelelahan Kerja Dengan Kinerja Perawat Di Bangsal Rawat Inap Rumah Sakit Islam Fatimah Kabupaten Cilacap," Jurnal KESMAS UAD, vol. 6, no. 2, pp. 162-232, 2012. 